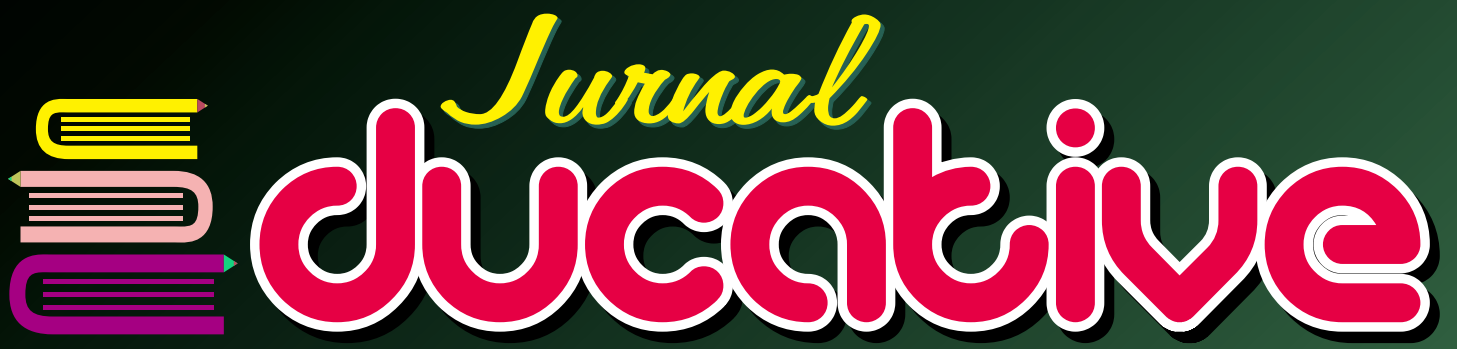 Journal of Educational Studies
}

Pengembangan Bahan Ajar Menulis Ringkasan dan Ikhtisar pada Mata Kuliah Pengembangan Keterampilan Menulis FKIP Universitas Baturaja Muhamad Doni Sanjaya, Muhamad Rama Sanjaya Upaya Meningkatkan Kemampuan Guru Menerapkan Penggunaan Bahan Ajar di SMA Negeri 3 Ogan Komering Ulu Aryanti Agustina

The Islamic Education Strategies Inlocal Culture Perspective of West Sumatera Society

Zulfani Sesmiarni, Junaidi, Darul Ilmi, Wedra Aprison

Problems In Learning Reading

(Case Study: Islamic Banking Students of IAIN Bukittinggi) Widya Syafitri

Teori Laactract dalam Persahabatan Generasi Millenial Qolbi Khoiri

e-Modul Computer Based Learning sebagai e-Resource Digital Literacy bagi Mahasiswa

Novrianti, Nofri Hendri, Ulfia Rahmi

Pengembangan Media Pembelajaran Mobile Learning berbasis Android Pada Mata Kuliah Kecerdasan Buatan Agus Nur Khomarudin, Liza Efriyanti

Meningkatkan Hasil Belajar Siswa Menggunakan Model Make a Match pada Mata Pelajaran IPS Kelas IV di SDN 11 OKU Yelmi Yunarti 


\title{
PENGEMBANGAN MEDIA PEMBELAJARAN MOBILE LEARNING BERBASIS ANDROID PADA MATA KULIAH KECERDASAN BUATAN
}

\author{
Agus Nur Khomarudin \\ Pendidikan Teknik Informatika dan Komputer, FTIK IAIN Bukittinggi \\ E-mail:agusnurkhomarudin@gmail.com
}

Liza Efriyanti

Pendidikan Teknik Informatika dan Komputer, FTIK LAIN Bukittinggi

E-mail : lizafamuth@yahoo.com

Muhammad Tafsir

Pendidikan Teknik Informatika dan Komputer, FTIK IAIN Bukittinggi

E-mail:mtafsir763@gmail.com

\section{Abstract}

This study aims to develop and produce android-based mobile learning on validated artificial intelligence course to describe its validity, practicality, and effectiveness. This is a research and development study that through five stages, which are Analysis, Design, Development, Implementation and Evaluation (ADDIE). The model used for this study is the Luther-Sutopo version of multimedia development model that consist of six stages; conceptualization, design construction, material collection, execution, examination and distribution. The results of this study found that (1) validity test from 2 multimedia experts showed the value of 94 with very valid category; (2) practicality test from 2 material experts showed the value of 92.88 with very practical category; and (3) effectiveness test from 9 university students on artificial intelligence course showed the value of 93.63 with very effective category. Based on the validity, practicality, and effectiveness test results, the mobile learning is considered feasible and can be used in the artificial intelligence course. Thus, it is recommended for the lecturers and university students to use it as one of alternative media of learning.

Keywords: instructional media, mobile learning, android, artificial intelligence.

\section{Abstrak}

Penelitian ini bertujuan untuk mengembangkan dan menghasilkan media pembelajaran mobile learning berbasis android pada mata kuliah kecerdasan buatan yang tervalidasi dan mendeskripsikan kevalidan, kepraktisan dan keefektifannya. Penelitian ini merupakan Research and Development dengan lima tahapan (ADDIE), yaitu Analisis, Desain, Pengembangan/Development, Implementasi dan Evaluasi. Model pengembangan yang digunakan adalah model pengembangan multimedia versi Luther-Sutopo yang terdiri dari enam tahap, yaitu pengonsepan, pendesainan, pengumpulan materi, pembuatan, pengujian dan pendistribusian. Hasil penelitian menunjukkan bahwa (1) uji validitas dari 2 orang ahli media menunjukkan nilai 94 dengan kategori sangat valid; (2) uji praktikalitas dari 2 orang ahli materi menunjukkan nilai 92,88 dengan kategori sangat praktis; (3) uji efektifitas dari 9 orang mahasiswa pada perkuliahan kecerdasan buatan menunjukkan nilai 93,63 dengan kategori sangat efektif. Berdasarkan hasil uji validitas, praktikalitas dan efektifitas, maka produk m-learning dinilai layak dan dapat digunakan pada pembelajaran mata kuliah kecerdasan buatan. Sehingga disarankan dosen dan mahasiswa dapat memanfaatkannya sebagai salah satu alternatif media pembelajaran.

Kata Kunci: Media Pembelajaran, Mobile Learning, Android, Kecerdasan Buatan.

\section{Pendahuluan}

Kemajuan Teknologi dan Informasi (TIK) saat ini memberikan pengaruh yang besar terhadap bidang pendidikan. Perkembangan TIK dapat dimanfaatkan pendidik dalam menciptakan media 
pembelajaran yang bervariasi dan menarik bagi peserta didik. Upaya menciptakan media pembelajaran yang bervariasi dan menarik diharapkan dapat menunjang keaktifan, kreativitas peserta didik yang pada akhirnya dapat meningkatkan hasil belajar peserta didik.

Penggunaan media dalam pembelajaran dapat membantu keterbatasan pendidik dalam menyampaikan informasi maupun keterbatasan jam pelajaran di kelas. Media berfungsi sebagai sumber informasi materi pembelajaran maupun sumber soal latihan (Resti et al., 2016, p. 89). Media pembelajaran dapat dibuat dan dirancang sesuai dengan perkembangan teknologi saat ini, diantaranya dikolaborasikan dengan memanfaatkan smartphone atau yang dikenal dengan istilah mobile learning (m-Learning).

M-Learning merupakan bagian dari electronic learning (e-learning) yang memungkinkan pendidik menyampaikan bahan ajar kepada peserta didik menggunakan media berbasis handphone. M-Learning memungkinkan peserta didik dapat melakukan kegiatan berupa materi pembelajaran, arahan dan informasi pembelajaran di mana pun dan kapan pun tidak terbatas ruang dan waktu. $M$ Learning juga mampu mengatasi keterbatasan alokasi waktu untuk materi tertentu. $M$ Learning juga mampu melatih peserta didik untuk belajar mandiri dari berbagai sumber yang disediakan (Yuniati, 2011).

Kecerdasaan buatan merupakan mata kuliah wajib bagi semester VI (Enam) di Prodi Pendidikan Teknik Informatika dan Komputer (PTIK) IAIN Bukittinggi, dengan bobot 3 SKS. Padatnya materi mata kuliah dan ketidakhadiran dosen dalam perkuliahan menyebabkan perkuliahan ini selesai tidak tepat waktu. Berdasarkan observasi yang telah dilakukan pada perkuliahan kecerdasan buatan kelas PTIK.VI A, diketahui bahwa lebih dari $80 \%$ dari 35 mahasiswa telah memiliki smartphone android. Tetapi belum dimanfaatkan untuk mengakses materi perkuliahan, sebagian besar mahasiswa justru banyak mempergunakan untuk mengakses media sosial. Kondisi lainnya adalah akses internet yang dapat menjangkau seluruh area yang ada di kampus IAIN Bukittinggi, sehingga sangat mendukung terciptanya m-learning pada mata kuliah tersebut.

Perangkat lunak (software) dan aplikasi yang digunakan untuk merancang m-learning saat ini telah banyak dan beragam, baik offline maupun online. Aplikasi appypie atau appypie.com merupakan salah satu aplikasi online yang dapat digunakan untuk merancang m-learning. Perangkat lunak ini dapat menciptakan aplikasi Android yang dapat diakses tanpa membutuhkan biaya dan dapat membantu menyelesaikan proses development aplikasi, dari perencaan hingga proses launching di Google Play Store. Hal yang diunggulkan dari produk ini adalah bahwa appypie tidak membutuhkan kemampuan coding atau pengalaman membangun aplikasi seperti programmer pada umumnya. Pengguna hanya perlu mengakses software ini, kemudian melakukan langkahlangkah pembuatan aplikasi sesuai instruksi dengan cermat. Kemudian tinggal menunggu beberapa saat hingga proses developing selesai, dan aplikasinya sudah siap diluncurkan dan diunduh.

Berdasarkan uraian yang dikemukakan di atas, peneliti telah membuat suatu media pembelajaran berbasis android yang menyajikan materi perkuliahan kecerdasan buatan lebih menarik. Tujuan utama penulis melakukan penelitan pengembangan ini untuk menghasilkan suatu media pembelajaran $m$ Learning berbasis android pada mata kuliah kecerdasan buatan, mendeskripsikan kevalidan, kepraktisan, dan keefektifannya.

\section{Landasan Teori}

Media Pembelajaran, Dalam proses belajar mengajar yang pada hakikatnya juga merupakan proses komunikasi, informasi atau 
pesan yang dikomunikasikan adalah isi atau bahan ajar yang telah ditetapkan dalam kurikulum, sumber informasi adalah guru, penulis buku atau perancang dan pembuat media pembelajaran lainnya; sedangkan penerimaan informasi adalah siswa atau warga belajar. Pengertian media pembelajaran bervariasi. Ada ahli media yang membuat definisi yang mengacu hanya pada alat atau perangkat keras, ada juga yang menonjolkan perangkat lunak.

Definisi yang mengacu pada perangkat keras adalah definisi yang dikemukakan oleh Schramm dan Briggs. Schramm mendefinisikan media pembelajaran sebagai teknologi pembawa informasi yang dapat dimanfaatkan untuk proses belajar mengajar; sedangkan Briggs mendifikasikannya sebagai sarana fisik untuk menyampaikan bahan ajar. Secara harfiah kata media memiliki arti "perantara" atau "pengantar".

Kata "Media" berasal dari bahasa latin yang merupakan bentuk jamak dari "medium", secara harfiah berarti perantara atau pengantar. Association for Education and Communication Technology (AECT), mengartikan kata media sebagai segala bentuk dan saluran yang dipergunakan untuk proses informasi. National Education Association (NEA) mendefinisikan media sebagai segala benda yang dapat dimanipulasikan, dilihat, didengar, dibaca atau dibicarakan beserta instrumen yang dipergunakan untuk kegiatan tersebut.

Berdasarkan uraian diatas maka secara singkat dapat dikemukakan bahwa media pembelajaran itu merupakan wahana penyalur pesan atau informasi belajar.

Keterlibatan media pembelajaran dalam proses pembelajaran diharapkan dapat mempengaruhi hasil belajar, semakin kongkrit pembelajaran yang diajarkan dan dirasakan oleh siswa maka pembelajaran semakin efektif. Hal ini senada dengan yang digambarkan oleh Edgar Dale.

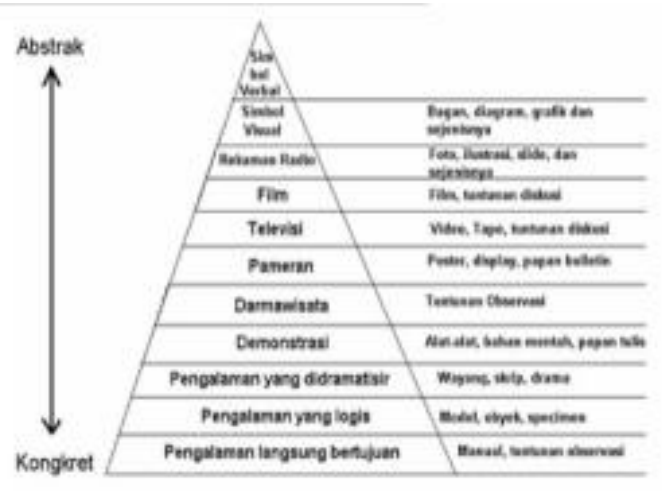

Gambar 2. Dale's Cone of Experience
Pada gambar diatas dapat kita lihat bahwa penggunaan media real object dianggap paling efektif dalam mencapai tujuan pembelajaran. Sehingga mampu mengatasi kesulitan belajar siswa dan perbedaan gaya belajar. Oleh karena itu dengan penggunaan bahan ajar multimedia interaktif sebagai media pembelajaran mampu menampilkan dan menyajikan materi pembelajaran yang lebih konkrit dan mudah dipahami siswa dibanding dengan belajar abstrak dengan teknik belajar verbal saja.

(b). Mobile Learning, Istilah Mobile Learning ( $m$ learning) mengacu kepada penggunaan perangkat/divais teknologi informasi (TI) genggam dan bergerak, seperti PDA, telepon genggam, laptop dan tablet PC, dalam pengajaran dan pembelajaran. M-Learning merupakan bagian dari electronic learning (elearning) sehingga, dengan sendirinya, juga merupakan bagian dari distance learning (dlearning).

Menggunakan mobile learning, pengguna dapat mengakses konten pembelajaran dimana saja dan kapan saja, tanpa harus mengunjungi suatu tempat tertentu pada waktu tertentu. Tujuan dari pengembangan mobile learning adalah proses belajar sepanjang waktu (long life learning), peserta didik dapat lebih aktif dalam proses pembelajaran karena sebelum hadir saat tatap muka nantinya peserta didik telah diperkaya dengan pengetahuan tentang pelajaran dari materi yang ada pada telepon genggam mereka, sehingga saat tatap muka 
memungkinkan peserta didik bertanya mengenai pembelajaran yang bersangkutan.

Konten Mobile Learning : (a). Teks, Kebanyakan divais saat ini telah mendukung penggunaan teks. hampir semua telepon seluler yang beredar saat ini telah mendukung penggunaan SMS (Short Message Servis). Kebutuhan memori yang relatif kecil memuat konten berbasis teks lebih mudah diimplementasikan. Namun, keterbatasan jumlah karakter yang dapat ditampilkan harus menjadi pertimbangan dalam menampilkan konten pembelajaran dapat disampaikan secara tepat dan efektif meskipun dengan keterbatasan ini. (b). Gambar, Divais bergerak yang ada sekarang telah banyak mendukung pemakaian gambar. Kualitas gambar yang dapat ditampilkan dapat beragam dari tipe monokrom sampai gambar berwarna kualitas tinggi tergantung kemampuan divais. Penggunaan gambar sebagai konten pembelajaran biasanya digabungkan dengan konten lain, misalkan teks. (c). Audio, File audio biasanya memiliki ukuran yang cukup besar, menyebabkan file audio tersebut harus diolah terlebih dahulu sehingga dapat digunakan di lingkungan divais bergerak yang memiliki kapasitas memori yang relatif kecil. (d). Video, Meski dalam kualitas ukuran yang terbatas, beberapa tipe divais bergerak telah mampu memainkan file video. Sama seperti file audio, kebanyakan file audio memiliki ukuran cukup besar.

Kelebihan m-learning diantaranya adalah : (a). Dapat digunakan dimana-pun pada waktu kapan-pun. (b). Kebanyakan divais bergerak memiliki harga relatif murah dibanding PC desktop. (c). Ukuran relatif kecil dan ringan dibanding PC desktop. (d). Diperkirakan dapat mengikut sertakan lebih banyak pembelajar karena m-learning memanfaatkan teknologi yang biasa digunakan dalam kehidupan seharihari.

Meski memiliki beberapa kelebihan, $m$ learning memiliki keterbatasan-keterbatasan terutama dari sisi perangkat/media belajarnya. Keterbatasan perangkat bergerak sebagai berikut : (a). Kemampuan prosessor. (b). Kapasitas memori. (c). Layar tampilan. (d). Catu daya. (e). Perangkat I/O.

(c). Teknologi yang digunakan, Appypie adalah salah satu media pengembangan software untuk membuat aplikasi android berbasis cloud yang terbaik. Perangkat lunak ini dapat menciptakan aplikasi Android yang dapat diakses tanpa membutuhkan biaya dan dapat membantu menyelesaikan proses development aplikasi, dari perencaan hingga proses launching di Google Play Store. Hal yang diunggulkan dari produk ini adalah bahwa Appypie tidak membutuhkan kemampuan coding atau pengalaman membangun aplikasi. Kita hanya perlu mengakses software ini, kemudian melakukan langkah-langkah pembuatan aplikasi sesuai instruksi dengan cermat. Kemudian tinggal menunggu beberapa saat hingga proses developing selesai, dan aplikasinya sudah siap diluncurkan dan diunduh.

$$
\text { Keunggulan Appypie ialah: }
$$

Penggunaan tidak memerlukan kemampuan coding, cukup dengan drag and drop. (b). Fitur revisi dan update aplikasi secara real-time. (c). Pengiriman push notification tanpa batas. (d). Aplikasi yang dibuat dapat dimonetized dengan iklan tertentu. (e). Mendukung berbagai macam pembuatan aplikasi sesuai dengan tema tertentu.

Langkah-langkah perancangan aplikasi menggunakan appypie : (1). Membuka web www.appypie.com (2). Klik Sign Up untuk registrasi. (3). Isi identitas sesuai kolom yang tersedia dengan lengkap. Apabila sudah melakukan sign up, selanjutnya membuka e-mail untuk memasukan kode verifikasi yang di kirim oleh appypie. Masukkan kode verifikasi yang sudah dikirim via e-mail kemudian klik verify, selanjutnya Create $A p p$ untuk membuat aplikasi. (4). Isi nama aplikasi (misal Momentum), dan pilih kategori "education" kemudian klik next. (5). Pilih tema sesuai yang diinginkan, kemudian klik next. Setelah itu, akan muncul kotak dialog. (6). Meghapus 
semua page yang tidak digunakan dengan cara mengklik page satu per satu lalu pilih tombol tempat sampah. Setelah semua page terhapus, kemudian tambahkan Textpage. Lalu mengganti gambar icon sesuai dengan yang kita inginkan dengan cara mengupload gambar, dan memberi nama page dengan profil, sk-kd, peta konsep dan lain-lain. (7). Selanjunya mengisi aplikasi profil, dan untuk melihat tampilan pada layar handphone kilk tombol android. (8). Membuat isi SK-KD. (9). Membuat isi Peta Konsep (untuk menambahkan gambar klik upload gambar/video). (10). Membuat materi. (11). Membuat contoh soal dengan format JPEG. (12). Membuat isi Simulasi yaitu dengan mengupload video pembelajaran yang sesuai dengan pokok bahasan. (13). Membuat Evaluasi dengan Quis, Untuk membuat kuis perlu dilakukan pengaturan sesuai dengan gambar dibawah yaitu dengan memberi nama kuis dan mencetang semua kotak-kotak kecil yang terdapat di halaman kuis. Kuis dapat dibuat apabila seluruh aplikasi telah selesai (save and finish). (14). Membuat Banner (gambar berjalan) Pilih halaman theme customization lalu cari list advanced setting kemudian mencentang show banner lalu add images. Setelah itu akan muncul kotak dialog untuk mengupload gambar. Untuk mengatur jenis huruf, warna huruf, ukuran huruf, dan warna backgroud pada heading, klik theme customization kemudian style \& navigation. Untuk mengatur jenis huruf, warna huruf dan ukuran huruf pada materi yang akan dibuat, klik theme customization kemudian page style \& colour scheme. (15). Merubah icon aplikasi dan tampilan splash, pilih theme customization. Untuk menggati icon bisa dengan upload gambar atau memilih icon yang sudah ada di web. (16). jika semua program sudah selesai tunggu beberapa menit, file apk akan dikirim ke e-mail. (17). Setelah menerima e-mail apk dari appy pie langkah selanjutnya yaitu mendownload file nya dengan mengklik url: http://apps.appypie.com./media/appfile/973 1631e86dc.apk (18). Setelah dilakukan download, file apk dipindahkan ke hp android untuk dilakukan instalasi. (19). Langkah berikutnya yaitu memasang apk di hp android (instal) dengan cara menekan file .apk nya. (20). Aplikasi sudah berhasil dipasang dan siap dijalankan.

\section{Metodologi Penelitian}

Dalam penelitian ini, penulis menggunakan Metode Penelitian dan Pengembangan (Research and Development) atau R\&D. Metode R\&D atau penelitian dan pengembangan adalah metode penelitian yang digunakan untuk menghasilkan produk tertentu, dan menguji keefektifan produk tersebut. Model Research and Development yang diterapkan adalah versi ADDIE. ADDIE merupakan singkatan dari Analysis - Design Development - Implement - Evaluate. Model pengembangan yang digunakan adalah model Pengembangan Multimedia versi LutherSutopo.

Menurut Luther (1994), model pengembangan multimedia terdiri dari enam tahap, yaitu Concept (pengonsepan), Design (pendesainan), Material Collecting (pengumpulan materi), Assembly (pembuatan), testing (pengujian), distribution (pendistribusian). Tahap-tahap tersebut dapat saling bertukar posisi tidak harus berurutan, meskipun begitu tahap concept memang harus menjadi hal yang pertama kali dikerjakan.

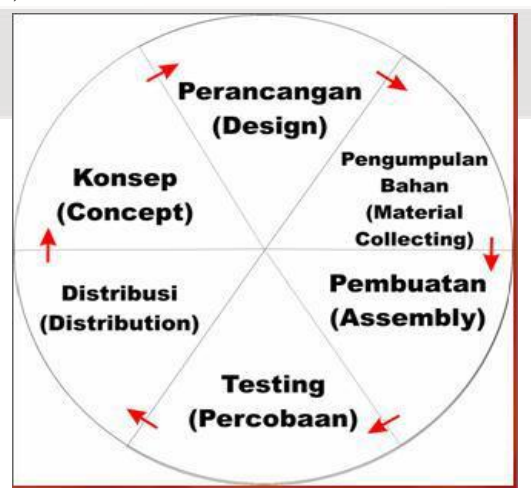

Gambar 2. Tahapan pengembangan multimedia 
Berdasarkan uraian di atas, maka dapat digambarkan tahapan penelitian seperti pada gambar 1 di bawah ini :

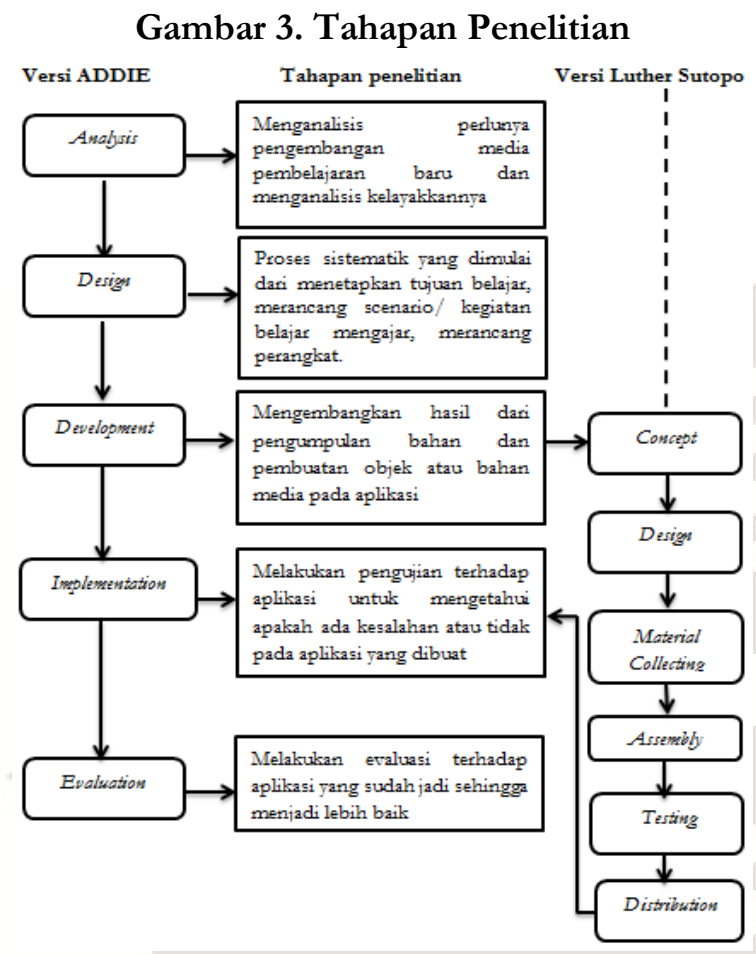

Tahap Concept; Pada tahap ini dilakukan penentuan tujuan yang meliputi tujuan media, identifikasi pengguna serta bentuk media. (2). Tahap Design (Perancangan). Pada tahap ini dilakukan untuk membuat spesifikasi dari arsitektur mobile learning, gaya, tampilan, dan kebutuhan material/bahan untuk media. Menguji bentuk pelaksanaan dan metode tes yang sesuai. Dalam tahap desain ini dilakukan perancangan : (a). Struktur Navigation; Struktur navigasi merupakan alat bantu dalam merancang aliran aplikasi m-learning; (b). ser Interface; User Interface (antar muka pengguna) adalah bagian aplikasi yang mengadakan interaksi dengan pengguna (user). User Interface dapat menerima informasi dari pengguna (user) dan memberikan informasi kepada pengguna (user) untuk membantu mengarahkan alur penelusuran masalah sampai ditemukan suatu solusi. Yang terpenting dalam membangun User Interface adalah kemudahan dalam memakai/menjalankan sistem, interaktif dan komunikatif; (3). Tahap Material Collecting (Pengumpulan Bahan). Tahap ini adalah tahap pengumpulan bahan yang sesuai dengan kebutuhan yang akan dikerjakan sesuai image, background, video, teks, dan bahan-bahan lain yang dibutuhkan untuk pembuatan aplikasi sesuai dengan desain yang telah dilakukan sebelumnya. (1). Tahap Assembly (Pembuatan); (2). Tahap ini merupakan tahap pembuatan semua objek atau bahan media. Pembuatan aplikasi ini menggunakan software (perangkat lunak) Appypie; (3). Tahap Testing (Pengujian). Pada tahap Testing ini dilakukan pengujian, dilakukan apabila selesai proses pembuatan dengan cara menjalankan aplikasi/program dan melihat apakah ada kesalahan pada aplikasi atau aplikasi tersebut berjalan sesuai dengan keinginan; (4). Tahap Distribution (Penyebaran); Tahap Penyebaran merupakan tahap penyimpanan aplikasi ke media penyimpanan.

Uji validitas produk dilakukan dengan menggunakan instrumen angket. Instrumen angket validasi diisi oleh dua orang ahli desain yang berkompeten dibidangnya. Uji praktikalitas produk juga menggunakan instrumen angket yang diisi oleh dua orang ahli materi yaitu dosen mata kuliah kecerdasan buatan. Sedangkan instrumen angket untuk uji efektifitas produk diisi oleh mahasiswa yang mempelajari mata kuliah kecerdasan buatan, dipilih secara acak tiga orang mahasiswa yang berkemampuan tinggi, tiga orang mahasiswa berkemampuan sedang dan tiga orang mahasiswa berkemampuan rendah.

Analisis validitas, praktikalitas dan efektifitas media pembelajaran berupa aspek tampilan, aspek instruksional desain, aspek validasi isi, dan kebahasan dilakukan dengan langkah berikut : (a). Memberikan skor jawaban setiap indikator dengan kriteria skala likert. 1 = Sangat Kurang; 2 = Kurang; 3 = Kukup; 4 = Baik; 5 = Sangat baik. (a). Menentukan jumlah skor dari masing-masing 
responden dengan menjumlahkan semua skor yang diperoleh dari masing-masing indikator, dengan rumus :

$$
N=\frac{B P}{B M} \times 100 \%
$$

Pada rumus skor di atas $\mathrm{N}$ merupakan nilai didapat, $B P$ merupakan bobot yang diperoleh dari angket yang diberikan, $B M$ merupakan bobot maksimal untuk setiap butir pernyataan pada angket. (a). Perhitungan data nilai akhir validasi dengan menggunakan kriteria skala likert:

Tabel 1. Kriteria validitas, praktikalitas dan efektifitas

\begin{tabular}{|c|c|c|c|}
\hline Presentase & $\begin{array}{c}\text { Kriteria } \\
\text { Valid }\end{array}$ & $\begin{array}{c}\text { Kriteria } \\
\text { Praktis }\end{array}$ & $\begin{array}{c}\text { Kriteria } \\
\text { Efektif }\end{array}$ \\
\hline $0-20$ & Tidak & Tidak & Tidak \\
& Valid & Praktis & Efektif \\
\hline $21-40$ & Kurang & Kurang & Kurang \\
& Valid & Praktis & Efektif \\
\hline $41-60$ & Cukup & Cukup & Cukup \\
& Valid & Praktis & Efektif \\
\hline $61-80$ & Valid & Praktis & Efektif \\
\hline $81-100$ & Sangat & Sangat & Sangat \\
& Valid & Praktis & Efektif \\
\hline
\end{tabular}

\section{Hasil dan Pembahasan}

\section{Analisis (Analyze)}

Merupakan tahapan pertama yang dilakukan sebelum pendesainan aplikasi. Pada tahap ini penulis melakukan observasi dan wawancara dengan dosen dan mahasiswa, yang pada dasarnya dosen dan mahasiswa mengharapkan adanya pemanfaatan teknologi dan informasi dalam perkuliahan khususnya pada media pembelajaran berbasis mobile.

\section{Desain (Design)}

Pada tahap ini penulis merancang $\mathrm{m}$ learning dengan isi materi yang sesuai dengan materi mata kuliah kecerdasan buatan. Selain itu juga dirancang beberapa menu yang akan ditampilkan pada aplikasi nantinya, seperti : menu materi, silabus, video tutorial, latihan/kuis dan profil author. Tahapan desain terdiri dari : desain sistem secara umum menggunakan alat bantu perancangan sistem yaitu Unified Modelling Language (UML), yang terdiri dari : usecase diagram, activity diagram dan sequence diagram; kemudian desain sistem secara khusus yang terdiri dari dua desain yaitu : desain output aplikasi dan desain teknologi.

\section{Pengembangan (Development)}

Pengembangan dalam model ADDIE berisi kegiatan realisasi rancangan produk. Dalam pengembangan media ini penulis menggunakan tahapan model pengembangan media yang dikembangkan oleh Luther Sutopo, sebagaimana berikut : (a). Pengonsepan (Concept); Media pembelajaran berbasis m-learning dengan menggunakan Appypie ini dirancang untuk mahasiswa program study PTIK IAIN Bukittinggi pada semester 6. Media yang dirancang ini bertujuan untuk menyampaikan materi pelajaran tentang kecerdasan buatan. Media mlearning yang dirancang akan dikemas dalam bentuk file apk selanjutnya dipasang (instal) pada smartphone android. Penyajian materi pembelajaranya menggunakan teks, gambargambar dan ditambah dengan video tutorial serta dilengkapi dengan soal latihan. (b). Desain Sistem (Design). Desain sistem diuraikan secara detail pada tahap ini yang terdiri dari dua macam desain, yaitu :

\section{Desain sistem secara umum}

Dalam mendesain sistem secara umum penulis menggunakan beberapa diagram dalam Unified Modelling Language (UML), yaitu :

\section{Usecase diagram}

Usecase diagram menggambarkan interaksi yang terjadi antara pengguna dengan aplikasi $m$ learning. Seperti yang terlihat pada gambar 2 di bawah ini : 


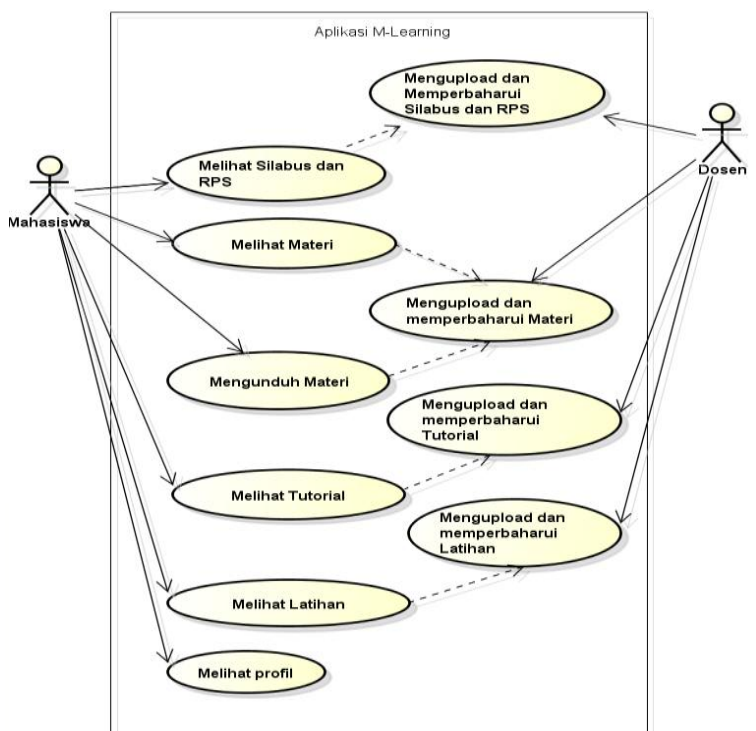

Gambar 4. Usecase diagram aplikasi mlearning

Berdasarkan diagaram use-case di atas dapat dilihat terdapat dua actor yaitu user (mahasiswa) dan admin (dosen) dan terdapat 10 usecase. Untuk tugas user, yaitu: akses melihat profil, akses melihat rps, akses melihat silabus, akses melihat materi, akses melihat tutorial dan akses melihat latihan. Sedangkan tugas dari admin (dosen) ialah: Mengupload dan memperbaharui rps, silabus, materi, tutorial dan latihan.

\section{Activity diagram}

Activity diagram menggambarkan berbagai alur aktivitas dalam sistem yang sedang dirancang, bagaimana masing-masing alur berawal, decision yang mungkin terjadi, dan bagaimana mereka berakhir. Activity diagram dari desain m-learning pada mata kuliah kecerdasan buatan menggunakan aplikasi appypie sebagai berikut:

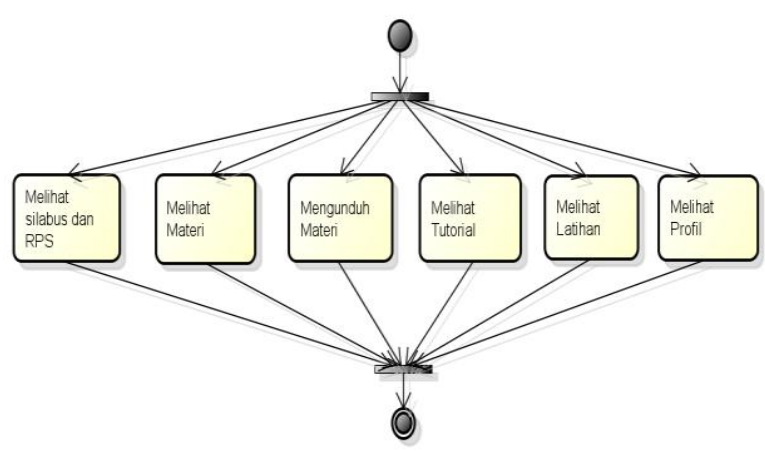

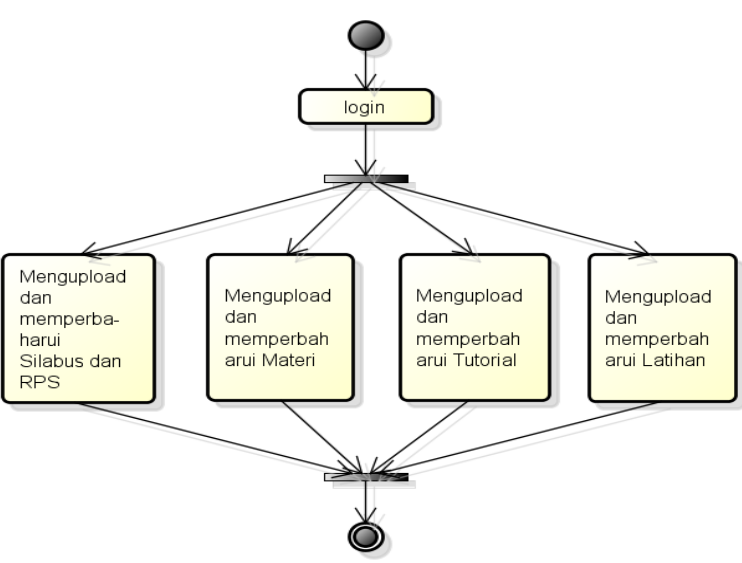

Gambar 6. Activity diagram admin

Sequence diagram

Sequence diagram aplikasi m-learning terdiri dari : Sequence diagram pada admin yaitu : mengupload dan memperbaiki silabus, RPS, materi, tutorial dan latihan. Sequence diagram pada mahasiswa yaitu : melihat silabus dan RPS, melihat dan mengunduh materi perkuliahan, melihat video tutorial, mengerjakan soal latihan dan melihat profil author.

Desain sistem secara khusus

Desain sistem secara khusus terdiri dari dua desain, yaitu : (a). Desain Output. Desain output m-learning yang dirancang diantaranya yaitu : desain tampilan splash screen, menu utama, menu silabus/RPS, tampilan materi, tampilan tutorial, tampilan soal latihan dan profil/author

Desain tampilan splash screen

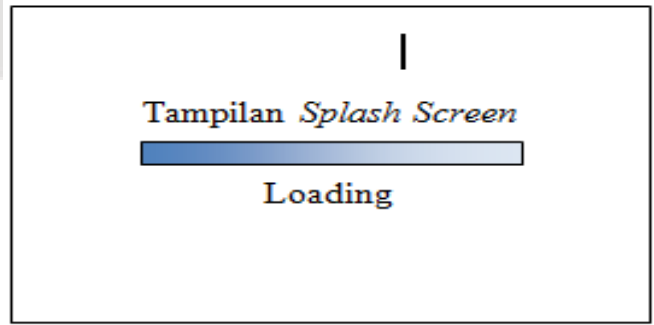

Gambar 7. Desain tampilan splash screen Desain menu utama

Gambar 5. Activity diagram mahasiswa 


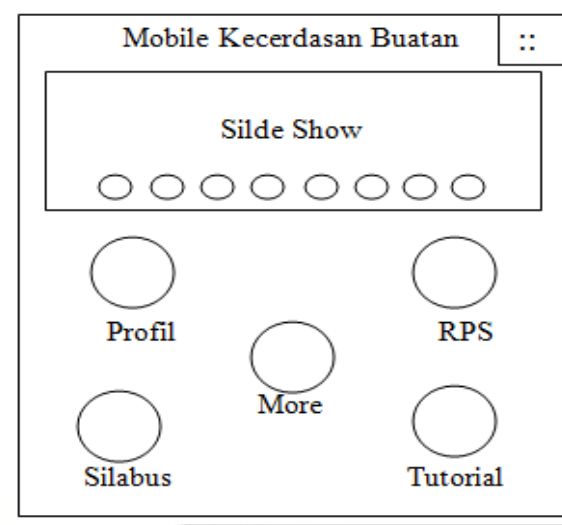

Gambar 8. Desain menu utama

Desain menu silabus/RPS

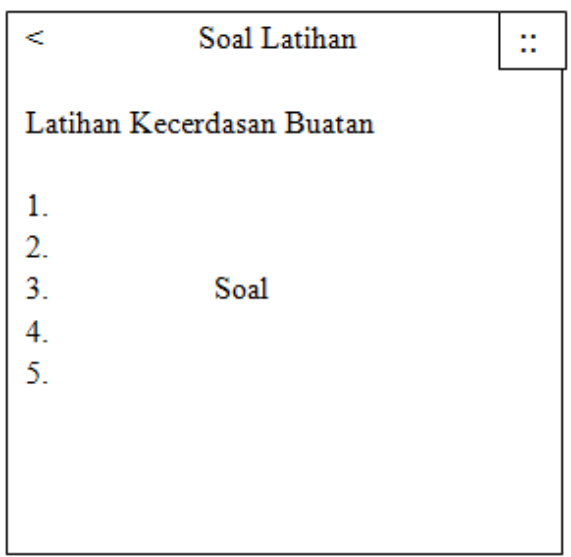

$<$ Rencana Pembelajaran Semester

Pengenalan rps kecerdasan buatan

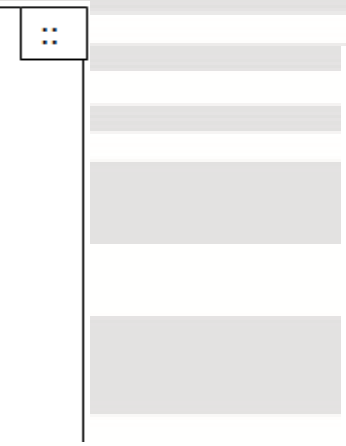

Gambar 12. Desain tampilan soal latihan Desain profil/author

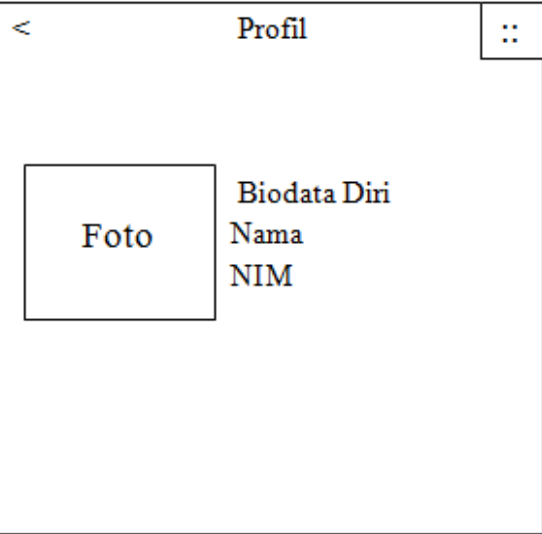

Gambar 9. Desain menu silabus/RPS

\section{Desain tampilan materi}

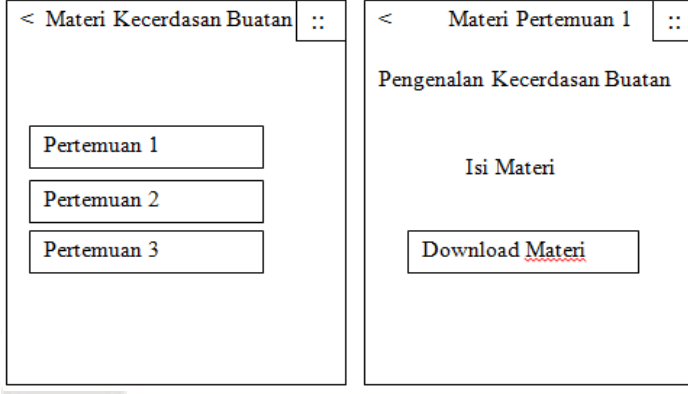

Gambar 10. Desain tampilan materi Desain tampilan tutorial

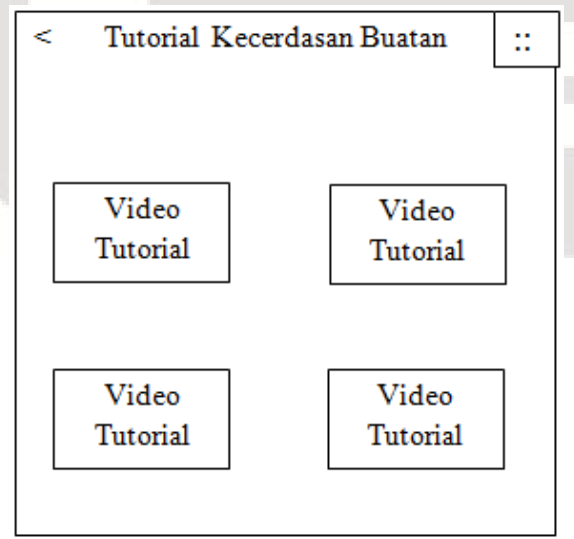

Gambar 11. Desain tampilan tutorial Desain tampilan soal latihan
Gambar 13. Desain tampilan profil/author

\section{Desain Teknologi}

Perangakat lunak (software) utama yang digunakan untuk merancang m-learning dalam penelitian ini adalah appypie atau appypie.com. Selain software harus diperhatikan yaitu hardware (tempat dimana aplikasi m-learning dapat dijalankan). Aplikasi m-learning yang dirancang dapat dijalankan pada smartphone android dengan spesifikasi sebagai berikut : sistem operasi android Lolipop 5.0 (minimal, direkomendasikan android versi 6.0/marshmallow), RAM minimal 512 MB, Resolusi layar minimal 4 inchi dan Kebutuhan ruang pemasangan aplikasi 30,23 MB.

\section{Pengumpulan Materi (Material Collecting)}

Merupakan tahap pengumpulan bahan untuk media yang dibuat, seperti : perangkat perkuliahan, gambar pendukung materi, icon 
untuk tombol, latar belakang (background), dan video tutorial. (1). Pembuatan (Assembly). Pembuatan m-learning pada appypie.com diawali dengan pembuatan akun terlebih dahulu, kemudian pilih menu education karena temanya adalah learning atau pendidikan, kemudian rancang nama aplikasi yang dibuat seperti "mokba-line", setelah itu memilih template untuk menu navigasi, kemudian mengisi materi/isi dari setiap menu navigasi.

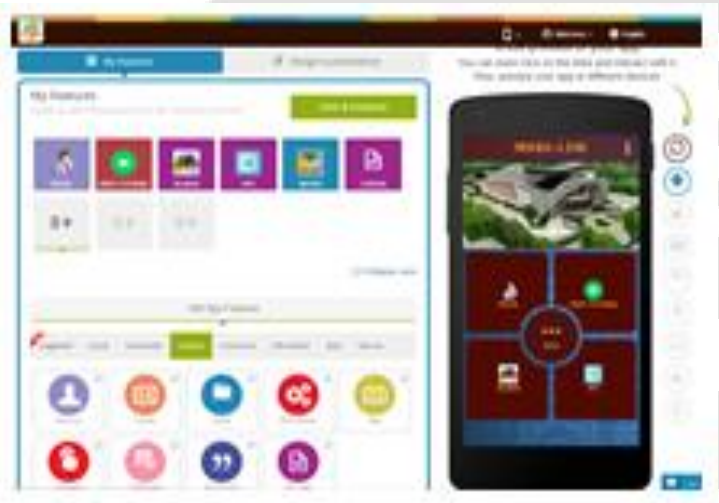

Gambar 14. Pembuatan tombol pada menu

\section{utama}

Pada tahap terakhir yaitu simulasi dan publikasi file apk yang selanjutnya dipasang atau install pada smartphone android untuk dilakukan pengujuan.
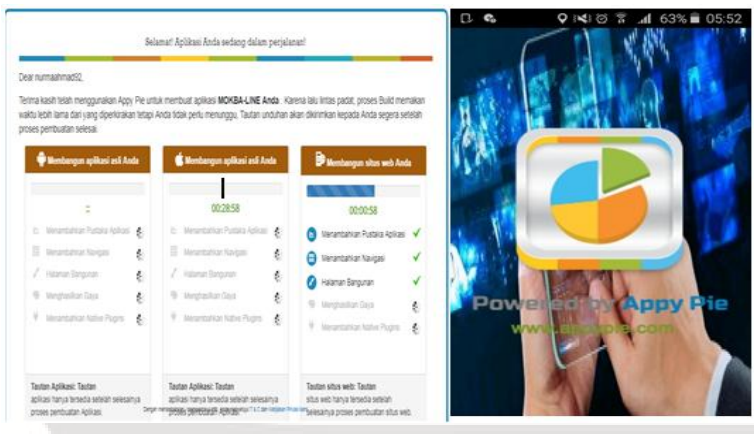

Gambar 15. Proses simulasi dan publikasi file

(2). Pengujian (Testing). Tahap pengujian dilakukan bertujuan untuk melihat apakah aplikasi m-learning ini dapat berjalan dengan baik dan sesuai dengan harapan. Pengujian dilakukan dengan meng-install file apk pada perangkat smartphone.

Pengujian yang penulis gunakan adalah metode blackbox testing. Blackbox testing merupakan salah satu metode pengujian perangkat lunak yang berfokus pada isi fungsionalitas, khususnya pada input aplikasi apakah sudah sesuai dengan yang diharapkan atau belum.

(a). Rencana pengujian. Pengujian aplikasi desain m-learning mata kuliah kecerdasan buatan dilakukan dengan menggunakan beberapa data uji berupa data masukan pada aplikasi yang telah dibuat. Adapun skenario pengujian m-learning ini dapat dilihat pada tabel 2 di bawah ini :

Tabel 2. Skenario pengujian aplikasi

\begin{tabular}{|c|c|c|}
\hline Kelas Uji & Butir Uji & Jenis Uji \\
\hline $\begin{array}{l}\text { Aplikasi m- } \\
\text { learning }\end{array}$ & $\begin{array}{l}\text { Membuka aplikasi } \\
\text { m-learning mata } \\
\text { kuliah kecerdasan } \\
\text { buatan }\end{array}$ & Black Box \\
\hline $\begin{array}{l}\text { Menu utama } \\
\text { desain } m \text { - } \\
\text { learning }\end{array}$ & $\begin{array}{l}\text { Menampilkan } \\
\text { tombol-tombol } \\
\text { atau list menu } \\
\text { utama }\end{array}$ & Black Box \\
\hline $\begin{array}{l}\text { Menu tombol } \\
\text { profil }\end{array}$ & $\begin{array}{l}\text { Menampilkan layar } \\
\text { profil programmer }\end{array}$ & Black Box \\
\hline Menu RPS & $\begin{array}{l}\text { Menampilkan layar } \\
\text { tentang RPS yang } \\
\text { ingin dicapai }\end{array}$ & Black Box \\
\hline Menu silabus & $\begin{array}{l}\text { Menampilkan layar } \\
\text { tentang silabus }\end{array}$ & Black Box \\
\hline Menu materi & $\begin{array}{l}\text { Menampilkan list } \\
\text { menu materi }\end{array}$ & Black Box \\
\hline Menu tutorial & $\begin{array}{l}\text { Menampilkan layar } \\
\text { tutorial materi }\end{array}$ & Black Box \\
\hline Menu latihan & $\begin{array}{l}\text { Menampilkan list } \\
\text { menu latihan }\end{array}$ & Black Box \\
\hline
\end{tabular}

Hasil Pengujian.

Berdasarkan implementasi aplikasi $m$ learning yang telah dilakukan maka dapat disimpulkan bahwa aplikasi ini dapat digunakan dan output yang di hasilkan telah sesuai dengan yang diharapkan. 
Tabel 3. Pengujian menu utama

\begin{tabular}{|c|c|c|c|}
\hline \multicolumn{4}{|c|}{ Kasus dan hasil uji } \\
\hline $\begin{array}{c}\text { Data } \\
\text { Masukan }\end{array}$ & $\begin{array}{c}\text { Yang } \\
\text { diharapkan }\end{array}$ & Pengamatan & Kesimpulan \\
\hline $\begin{array}{l}\text { Membuka } \\
\text { aplikasi } \\
\text { desain } \\
\text { mobile } \\
\text { learning }\end{array}$ & $\begin{array}{l}\text { Menampilkan } \\
\text { Menu Utama }\end{array}$ & $\begin{array}{l}\text { Dapat } \\
\text { menampilkan } \\
\text { tombol- } \\
\text { tombol atau } \\
\text { list Menu } \\
\text { Utama }\end{array}$ & Sukses \\
\hline
\end{tabular}

Tabel 4. Pengujian menu profil

\begin{tabular}{|l|l|l|l|}
\hline \multicolumn{4}{|c|}{ Kasus dan hasil uji } \\
\hline $\begin{array}{c}\text { Data } \\
\text { Masukan }\end{array}$ & $\begin{array}{c}\text { Yang } \\
\text { diharapkan }\end{array}$ & Pengamatan & Kesimpulan \\
\hline $\begin{array}{l}\text { Mengklik } \\
\text { menu } \\
\text { profil }\end{array}$ & $\begin{array}{l}\text { Menampilkan } \\
\text { layar profil }\end{array}$ & $\begin{array}{l}\text { Dapat mena } \\
\text { mpilkan layar } \\
\text { profil secara } \\
\text { keseluruhan }\end{array}$ & Sukses \\
\hline
\end{tabular}

Tabel 5. Pengujian menu RPS

\begin{tabular}{|l|l|l|l|}
\hline \multicolumn{4}{|c|}{ Kasus dan Hasil Uji } \\
\hline $\begin{array}{c}\text { Data } \\
\text { Masukan }\end{array}$ & \multicolumn{1}{|c|}{$\begin{array}{c}\text { Yang } \\
\text { diharapkan }\end{array}$} & Pengamatan & Kesimpulan \\
\hline $\begin{array}{l}\text { Mengklik } \\
\text { menu } \\
\text { RPS }\end{array}$ & Menampilkan & $\begin{array}{l}\text { Dapat } \\
\text { Renampilkan }\end{array}$ & Sukses \\
\hline
\end{tabular}

Tabel 6. Pengujian menu silabus

\begin{tabular}{|l|l|l|l|}
\hline \multicolumn{4}{|c|}{ Kasus dan Hasil Uj̈ } \\
\hline \multicolumn{1}{|c|}{$\begin{array}{c}\text { Data } \\
\text { Masukan }\end{array}$} & \multicolumn{1}{|c|}{$\begin{array}{c}\text { Yang } \\
\text { diharapkan }\end{array}$} & Pengamatan & Kesimpulan \\
\hline $\begin{array}{l}\text { Mengklik } \\
\text { menu } \\
\text { silabus }\end{array}$ & $\begin{array}{l}\text { Menampilkan } \\
\text { silabaus }\end{array}$ & $\begin{array}{l}\text { Dapat } \\
\text { menampilkan } \\
\text { silabus } \\
\text { kecerdasan } \\
\text { buatan }\end{array}$ & Sukses \\
& & & \\
\hline
\end{tabular}

Tabel 7. Pengujian menu materi

\begin{tabular}{|l|l|l|l|}
\hline \multicolumn{4}{|c|}{ Kasus dan Hasil Uji } \\
\hline $\begin{array}{c}\text { Data } \\
\text { Masukan }\end{array}$ & \multicolumn{1}{|c|}{$\begin{array}{c}\text { Yang } \\
\text { diharapkan }\end{array}$} & Pengamatan & Kesimpulan \\
\hline $\begin{array}{l}\text { Mengklik } \\
\text { menu } \\
\text { pertemua } \\
\text { n1 }\end{array}$ & $\begin{array}{l}\text { Menampilkan } \\
\text { isi atau mater } \\
\text { pertemuan 1 }\end{array}$ & $\begin{array}{l}\text { Dapat mena } \\
\text { mpilkan isi } \\
\text { atau mater } \\
\text { pertemuan 1 } \\
\text { sampai } \\
\text { dengan } \\
\text { pertemuan 3 }\end{array}$ & Sukses \\
\hline
\end{tabular}

Agus Nur K., Liza Efriyanti, Dkk.
Tabel 8. Pengujian menu tutorial

\begin{tabular}{|c|c|l|l|}
\hline \multicolumn{4}{|c|}{ Kasus dan Hasil Uji } \\
\hline $\begin{array}{c}\text { Data } \\
\text { Masukan }\end{array}$ & $\begin{array}{c}\text { Yang } \\
\text { diharapkan }\end{array}$ & Pengamatan & Kesimpulan \\
\hline $\begin{array}{l}\text { Mengklik } \\
\text { tutorial 1 }\end{array}$ & $\begin{array}{l}\text { Menampilkan } \\
\text { isi atau mater } \\
\text { tutorial 1 }\end{array}$ & $\begin{array}{l}\text { Video dapat } \\
\text { berjalan } \\
\text { dengan baik }\end{array}$ & Sukses \\
\hline
\end{tabular}

Tabel 9. Pengujian menu latihan

\begin{tabular}{|c|c|c|c|}
\hline \multicolumn{4}{|c|}{ Kasus dan Hasil $\mathrm{U}_{\mathbf{j}}$} \\
\hline $\begin{array}{c}\text { Data } \\
\text { Masukan }\end{array}$ & $\begin{array}{c}\text { Yang } \\
\text { diharapkan }\end{array}$ & Pengamatan & Kesimpulan \\
\hline $\begin{array}{c}\text { Mengkli } \\
\text { k menu } \\
\text { latihan }\end{array}$ & $\begin{array}{c}\text { Menampilkan } \\
\text { isi soal latihan } \\
\text { kecerdasan } \\
\text { buatan }\end{array}$ & $\begin{array}{c}\text { Dapat } \\
\text { menampilkan } \\
\text { soal latihan } \\
\text { kecerdasan } \\
\text { buatan }\end{array}$ & Sukses \\
\hline
\end{tabular}

Dari pengujian blackbox system yang telah penulis lakukan dapat disimpulkan bahwa semua kelas uji dan semua menu yang diujikan dapat berjalan dengan sukses.

\section{Distribusi (Distribution)}

Dalam tahap ini aplikasi yang sudah melalui tahap pengujian dan sudah menjadi file apk dapat disalin ke device android pengguna, kemudian dibuka untuk melalukan pemasangan (install).

\section{Implementasi}

Implementasi dilakukan dengan memasang (install) file apk pada perangkat smartphone, selanjutnya dilakukan uji coba produk meliputi: uji validitas, uji praktikalitas dan uji efektifitas.

\section{Hasil uji validitas}

Uji validitas produk dilakukan dengan menggunakan instrumen angket. Instrumen angket validasi diisi oleh dua orang ahli desain dan ahli multimedia yang berkompeten dibidangnya, serta memiliki pendidikan minimal S2. Angket uji validitas kepada ahli media terdiri dari 20 butir soal, yang terbagi dalam empat aspek yaitu : aspek validitas isi, aspek instruksional desain, aspek tampilan dan aspek kebahasaan. Selain itu, dalam angket uji validitas tersebut juga terdapat lampiran 
berupa masukan kritik dan saran yang akan diisi oleh para ahli yang berguna untuk evaluasi demi kesempurnaan aplikasi yang dibuat. Hasil skor penilaian dari dua orang ahli media dapat dilihat pada tabel 10 di bawah ini :

Tabel 10. Hasil uji validitas oleh 2 orang ahli media

\begin{tabular}{|c|c|c|c|c|c|}
\hline \multirow{5}{*}{ No } & \multirow{5}{*}{ Kriteria } & \multicolumn{4}{|c|}{ Validator } \\
\hline & & \multicolumn{2}{|c|}{$\begin{array}{c}\text { Rini Okra, } \\
\text { M.Kom }\end{array}$} & \multicolumn{2}{|c|}{$\begin{array}{c}\text { Rohaniatul } \\
\text { Husna, S.Pd, } \\
\text { M.Kom }\end{array}$} \\
\hline & & \multirow{3}{*}{ BP } & Hasil & \multirow{3}{*}{$\mathrm{BP}$} & Hasil \\
\hline & & & $\begin{array}{l}\text { (BP/ } \\
\text { BM) }\end{array}$ & & $\begin{array}{l}\text { (BP/ } \\
\text { BM) }\end{array}$ \\
\hline & & & $\mathbf{x} 100$ & & $\mathbf{x} 100$ \\
\hline 1 & AS PEK VALIDITAS ISI & 22 & $\begin{array}{l}(22 / 25)^{*} \\
100 \\
=88\end{array}$ & 23 & $\begin{array}{l}(23 / 25)^{*} \\
100 \\
=92\end{array}$ \\
\hline 2 & $\begin{array}{l}\text { AS PEK } \\
\text { INSTRUKSIONAL } \\
\text { DESAIN } \\
\end{array}$ & 24 & $\begin{array}{l}(24 / 25)^{*} \\
100 \\
=96\end{array}$ & 25 & $\begin{array}{l}(25 / 25)^{*} \\
100 \\
=100 \\
\end{array}$ \\
\hline 3 & TAMPILAN & 23 & $\begin{array}{l}(23 / 25)^{*} \\
100 \\
=92\end{array}$ & 23 & $\begin{array}{l}(23 / 25)^{*} \\
100 \\
=92\end{array}$ \\
\hline 4 & AS PEK KEBAHASAAN & 24 & $\begin{array}{l}(24 / 25)^{*} \\
100 \\
=96\end{array}$ & 24 & $\begin{array}{l}(24 / 25)^{*} \\
100 \\
=96\end{array}$ \\
\hline & RATA-RATA & & 93 & & 95 \\
\hline & HASIL VALIDASI & & & 94 & \\
\hline & KATEGORI & & Sanga & at $\mathrm{Va}$ & \\
\hline
\end{tabular}

Berdasarkan tabel 10. Hasil uji validitas dari para ahli media dapat dilihat bahwa hasil dari aspek validitas isi diperoleh rata-rata $(88+92) / 2=90$; aspek instruksional desain diperoleh rata-rata $(96+100) / 2=98$; aspek tampilan $(92+92) / 2=92$ dan aspek kebahasaan $(96+96) / 2=96$. Secara keseluruhan rata-rata penilaian yang diperoleh dari dua orang ahli media menunjukkan nilai 94 dengan kategori Sangat Valid.

\section{Hasil uji praktikalitas}

Uji praktikalitas produk juga menggunakan instrumen angket yang diisi oleh dua orang ahli materi yaitu dosen mata kuliah kecerdasan buatan. Lembar angket uji validitas kepada ahli media terdiri dari 12 butir soal, yang terbagi dalam 3 aspek yaitu aspek tampilan aplikasi, aspek isi materi dan aspek manfaat aplikasi. Selain itu, dalam angket uji praktikalitas tersebut juga terdapat lampiran berupa masukan kritik dan saran yang akan diisi oleh para praktisi dan berguna untuk evaluasi demi kesempurnaan aplikasi yang dibuat. Hasil skor penilaian dari dua orang ahli materi dapat dilihat pada tabel 11 di bawah ini:

Tabel 11. Hasil uji praktikalitas oleh 2 orang ahli materi

\begin{tabular}{|c|c|c|c|c|c|}
\hline \multirow{5}{*}{ No } & \multirow{5}{*}{ Kriteria } & \multicolumn{4}{|c|}{ Validator } \\
\hline & & \multicolumn{2}{|c|}{$\begin{array}{c}\text { Amelia } \\
\text { Permata } \\
\text { Sari, S.Pd, } \\
\text { M.Kom }\end{array}$} & \multicolumn{2}{|c|}{$\begin{array}{c}\text { Ryan } \\
\text { Am anda, } \\
\text { S.Pd, M.PdT }\end{array}$} \\
\hline & & \multirow{3}{*}{$\mathrm{BP}$} & Hasil & \multirow{3}{*}{ BP } & Hasil \\
\hline & & & $\begin{array}{l}\mathrm{BP} / \\
\mathrm{BM})\end{array}$ & & $\begin{array}{l}\text { (BP/ } \\
\mathrm{BM})\end{array}$ \\
\hline & & & $\mathrm{x} 100$ & & $\mathbf{x} 100$ \\
\hline 1 & TAMPILAN APLIKASI & 24 & $\begin{array}{l}(24 / 25)^{*} \\
100 \\
=96\end{array}$ & 22 & $\begin{array}{l}(22 / 25)^{*} \\
100 \\
=88\end{array}$ \\
\hline 2 & IS I MAT ERI & 18 & $\begin{array}{l}(18 / 20)^{*} \\
100 \\
=90\end{array}$ & 18 & $\begin{array}{l}(18 / 20)^{*} \\
100 \\
=90\end{array}$ \\
\hline 3 & MANFAAT APLIKASI & 14 & $\begin{array}{l}(14 / 15)^{*} \\
100 \\
=93,33 \\
\end{array}$ & 15 & $\begin{array}{l}(15 / 15)^{*} \\
100 \\
=100\end{array}$ \\
\hline & RATA-RATA & & 93,11 & & 2,66 \\
\hline & HASIL VALIDASI & \multicolumn{4}{|c|}{92,88} \\
\hline & KATEGORI & \multicolumn{4}{|c|}{ Sangat Praktis } \\
\hline
\end{tabular}

Berdasarkan tabel 11. Hasil uji praktikalitas dari para ahli materi dapat dilihat bahwa hasil dari aspek tampilan aplikasi diperoleh rata-rata $(96+88) / 2=92$; aspek isi materi diperoleh rata-rata $(90+90) / 2=90$; dan aspek manfaat aplikasi $(93,33+100) / 2=96,66$. Secara keseluruhan rata-rata penilaian yang diperoleh dari dua orang ahli materi menunjukkan nilai $\mathbf{9 2 , 8 8}$ dengan kategori Sangat Praktis.

\section{Hasil uji efektifitas}

Uji efektifitas diperoleh dengan menggunakan instrumen angket yang diisi oleh mahasiswa pada mata kuliah kecerdasan buatan kelas PTIK.VI A. Mahasiswa yang mengisi lembar angket dipilih secara acak tiga orang mahasiswa yang berkemampuan tinggi, tiga orang mahasiswa berkemampuan sedang dan tiga orang mahasiswa berkemampuan rendah. 
Hasil skor penilaian dari 9 orang mahasiswa dapat dilihat pada tabel 12 di bawah ini :

Tabel 12. Hasil uji efektifitas oleh mahasiswa

\begin{tabular}{|c|c|c|c|c|c|}
\hline \multirow[b]{2}{*}{ No } & \multirow[b]{2}{*}{ MAHASISWA } & \multicolumn{3}{|c|}{ KRITERIA } & \multirow[b]{2}{*}{$\begin{array}{l}\text { RATA- } \\
\text { RATA }\end{array}$} \\
\hline & & $\begin{array}{c}\text { ASPEK } \\
\text { TAMPILAN }\end{array}$ & $\begin{array}{c}\text { KETER- } \\
\text { PADUAN } \\
\text { ISI } \\
\text { PRODUK }\end{array}$ & $\begin{array}{l}\text { KEMAN- } \\
\text { FAATAN } \\
\text { APLIKASI }\end{array}$ & \\
\hline 1 & Fadilahtul Husna & 90 & 92 & 100 & 94,00 \\
\hline & Muhammad $T$ afs ir & 95 & 92 & 90 & 92,33 \\
\hline 3 & Najmi Nst & 90 & 88 & 90 & 89,33 \\
\hline & Nazir & 95 & 96 & 90 & 93,67 \\
\hline & Duri Rahma Puti & 95 & 100 & 80 & 91,67 \\
\hline & Nadia Putri & 100 & 96 & 100 & 98,67 \\
\hline & Deriant Putra E. & 95 & 96 & 100 & 97,00 \\
\hline & Muhammad Ilyas & 95 & 92 & 90 & 92,33 \\
\hline & Nil Fitri Yenti & 95 & 96 & 90 & 93,67 \\
\hline & Rata-rata & 94,44 & 94,22 & 92,22 & 93,63 \\
\hline \multicolumn{4}{|c|}{ HASIL VALIDASI } & \multicolumn{2}{|r|}{93,63} \\
\hline \multicolumn{4}{|c|}{ KATEGORI } & \multicolumn{2}{|c|}{ Sangat Efektif } \\
\hline
\end{tabular}

Berdasarkan tabel 12. Hasil uji efektifitas dari 9 orang mahasiswa dapat dilihat bahwa hasil dari aspek tampilan aplikasi diperoleh rata-rata 94,44; aspek keterpaduan isi produk diperoleh rata-rata 94,22; dan aspek kemanfaatan aplikasi 92,22. Secara keseluruhan rata-rata penilaian yang diperoleh dari 9 orang mahasiswa menunjukkan nilai 93,63 dengan kategori Sangat Praktis.

\section{Evaluasi}

Setelah penulis melakukan uji coba produk yang meliputi uji validitas, uji praktikalitas dan uji efektifitas, terdapat beberapa hal yang direvisi sesuai dengan komentar atau saran dari para ahli media dan ahli materi dalam lembar penilaian yaitu : (a). Ahli Media, menyarankan dua hal : 1). Revisi pada tampilan menu utama disarankan agar menggunakan model menu yang lebih interaktif, sehingga tampilan menu menjadi lebih menarik; 2). Dan juga materi pertemuan satu dan seterusnya agar disusun atau dikelompokkan sehingga sajian materi menjadi lebih berurutan dan sistematis. Dengan kata lain dijadikan sebagai sub menu dari menu Materi. (b). Ahli Materi; (1). Tampilan materi satu dan seterusnya disarankan supaya ada penambahan download materi. Materi yang dapat di-download disarankan seperti: file .pdf, .ppt, .doc.

\section{Revisi Media}

1). Revisi pada tampilan menu utama disarankan agar menggunakan model menu yang lebih interaktif, sehingga tampilan menu menjadi lebih menarik; Tampilan media setelah direvisi sesuai dengan yang disarankan tersebut di atas dapat dilihat pada gambar berikut :

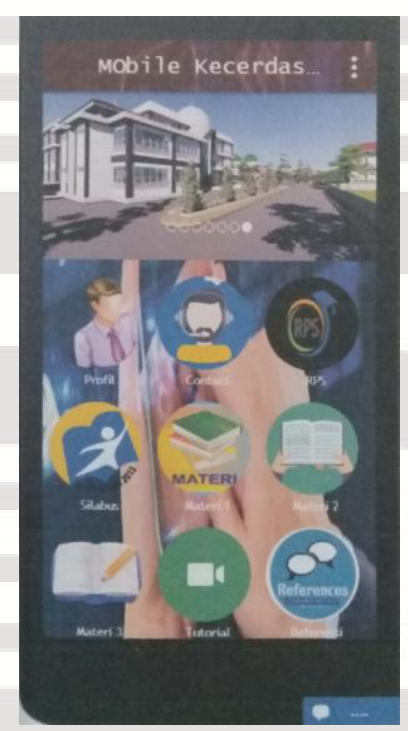

Gambar 16. Tampilan menu utama sebelum

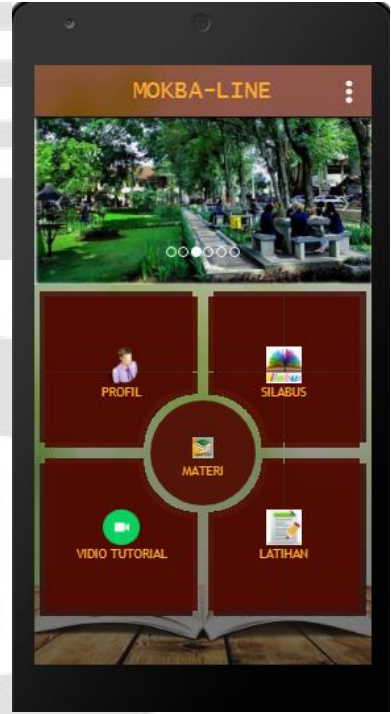

Gambar 17. Tampilan menu utama setelah direvisi
2). Dan juga materi pertemuan satu dan seterusnya agar disusun atau dikelompokkan sehingga sajian materi menjadi lebih berurutan dan sistematis.

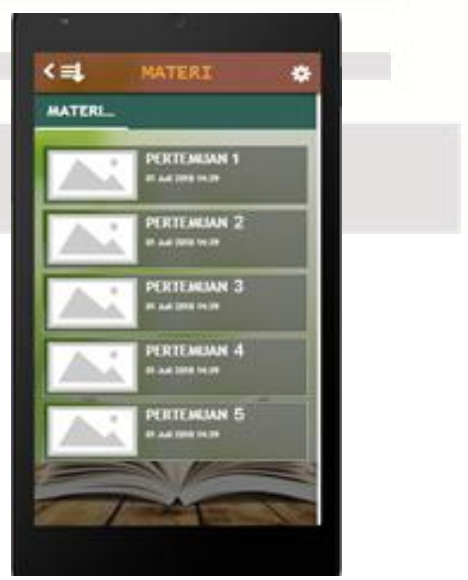

Gambar 18. Tampilan tambahan sub menu materi sesuai dengan saran ahli 
Tampilan materi satu dan seterusnya disarankan supaya ada penambahan download materi. Materi yang dapat di-download disarankan seperti: file .pdf; .ppt, .doc.

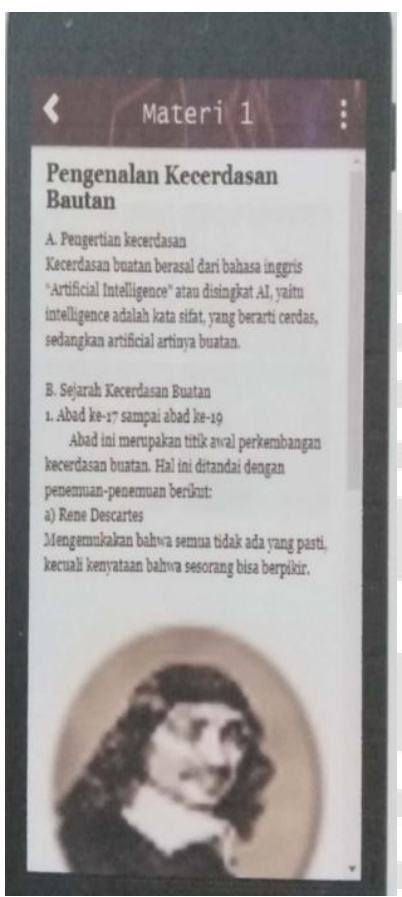

Gambar 19. Tampilan materi sebelum direvisi

(belum terdapat fasilitas download materi) (n)

Selain tampilan revisi di atas, penulis juga menambahkan beberapa tampilan atribut m-learning sebagai penyempurna hasil akhir produk mokba-line, yaitu : Tampilan awal mokba-line (index/splash screen), menu utama mokba-line, video tutorial, soal latihan/kuis, profil author dan silabus perkuliahan. Tampilan masing-masing terlihat pada gambar di bawah ini : fasilitas download materi)

Tampilan materi setelah direvisi (terdapat ad

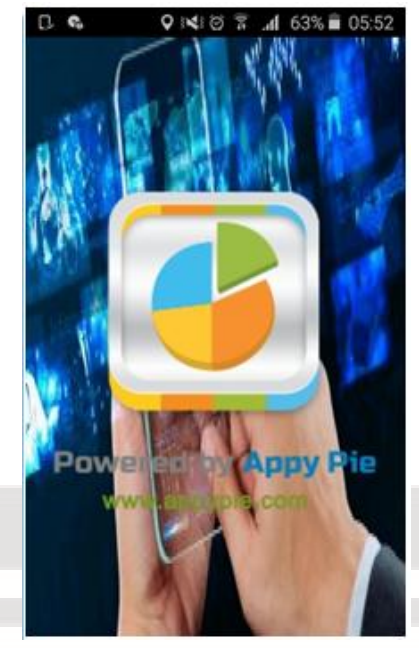

Gambar 21. Tampilan awal mokba-line (index/splash screen)

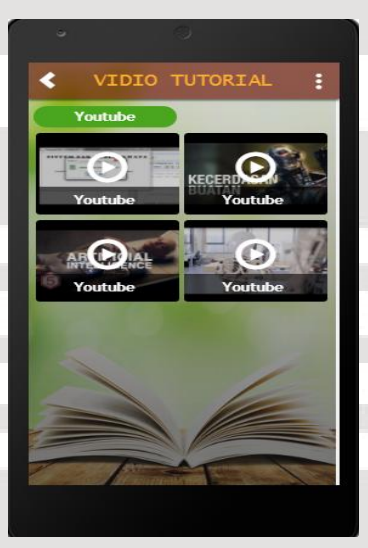

Gambar 23. Tampilan video tutorial

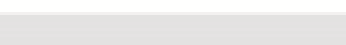

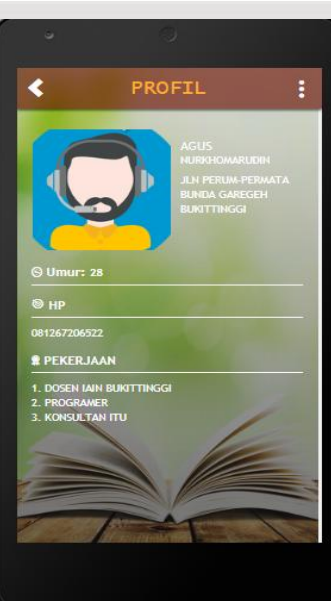

Gambar 25. Tampilan profil author

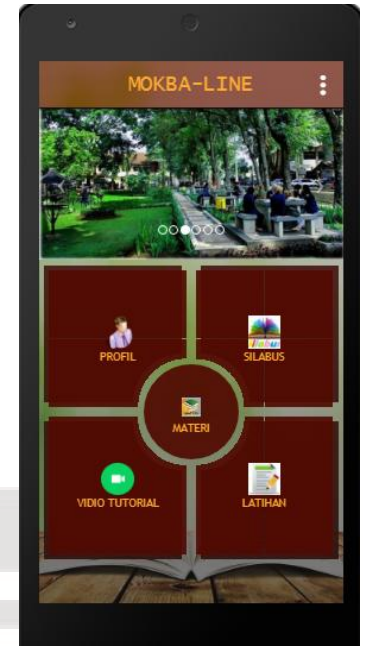

Gambar 22.

Tampilan menu utama mokba-line

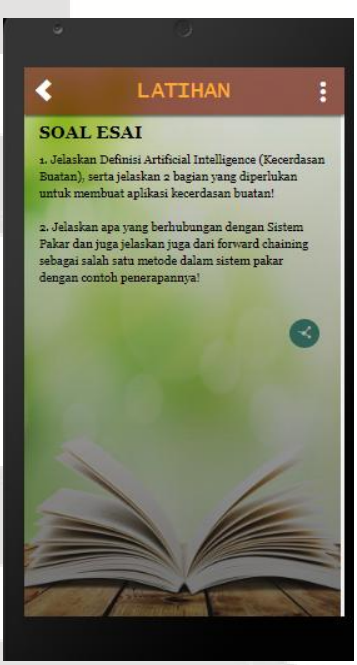

Gambar 24.

Tampilan soal latihan/kuis

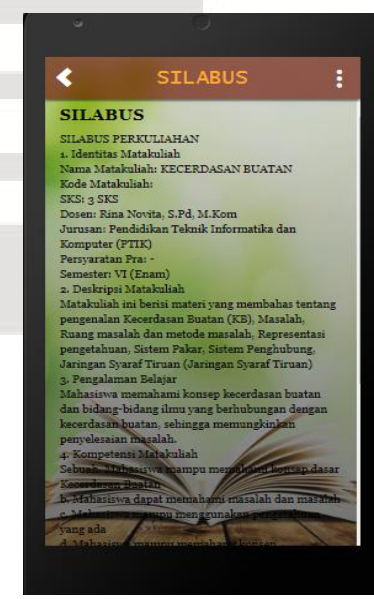

Gambar 26.

Tampilan silabus perkuliahan 


\section{Penutup}

\section{Kesimpulan}

Berdasarkan penelitian yang telah dilakukan tentang pengembangan media pembelajaran mobile learning berbasis android pada mata kuliah kecerdasan buatan maka diperoleh kesimpulan sebagai berikut : (1). Dihasilkan produk media pembelajaran m-learning berbasis android pada mata kuliah kecerdasan buatan; (2). Hasil uji validitas dari 2 orang ahli media menunjukkan nilai 94 dengan kategori sangat valid, hasil uji praktikalitas dari 2 orang ahli materi menunjukkan nilai 92,88 dengan kategori sangat praktis, hasil uji efektifitas dari 9 orang mahasiswa menunjukkan nilai 93,63 dengan kategori sangat efektif; (3). Berdasarkan hasil uji validitas, praktikalitas dan efektifitas seperti yang diuraikan pada poin 2 , maka produk $m$ learning dinilai layak dan dapat digunakan pada pembelajaran mata kuliah kecerdasan buatan.

Saran

Penelitian ini menghasilkan produk media pembelajaran m-learning berbasis android yang dinilai layak digunakan dalam pembelajaran, sehingga disarankan dosen dan mahasiswa dapat memanfaatkannya sebagai salah satu alternatif media pembelajaran. Media m-learning yang dirancang juga perlu dikembangkan dengan teknologi yang lain dan untuk materi perkuliahan selain dari kecerdasan buatan, sehingga dapat menunjang pelaksanaan pembelajaran di kampus.

\section{Daftar Pustaka}

Binanto, Iwan, Multimedia Digital, Dasar Teori+Pengembangannya, Andi Offset, 2010).

Budiman, Haris, Peran Teknologi Informasi dan Komunikasi dalam Pendidikan, AlTadzkiyyah : Jurnal Pendidikan Islam, Volume 8, Mei 2017.

Emzir, Metodologi Penelitian Pendidikan Kuantitatif \& Kualitatif, Jakarta: Rajawali Pers, 2015) hal. 263
Falahudin, Iwan, Pemanfaatan media dalam pembelajaran, Juliwi : Jurnal Lingkar Widyaiswara, Edisi 1, No.4, OktoberDesember 2014, h.108.

Hendri, Nofri dan Novrianti, Pengembangan Multimedia Interaktif Menggunakan Adobe Captive 7.0 pada Mata Kuliah Dasar-Dasar Komputer, Jurnal Educative : Journal of Educational Studies, Vol 2, No 2, JuliDesember 2017.

Idrus, Ali dan Andreo Yudherta, Pengembangan Augmented Reality Sebagai Media dalam Meningkatkan Pemahaman Teks Bacaan, Jurnal Teknologi Pendidikan, Vol. 18, No. 3, Desember 2016.

Saliman, Mukminan, Teknologi Informasi dan Media Pembelajaran IPS, (Yogyakarta: Universitas Negeri Yogyakarta, 2008).

Sriyanti, Ida, M-learning : Alternatif media pembelajaran di LPTK, Artikel Makalah Seminar Nasional pendidikan, 2009, h. 5-6.

Sugiyono, Metode Penelitian pendekatan Kuantitatif, Kualitatif, dan R\&D, (Bandung:Alfabeta, 2011) hal. 297

Suherman, Yuyus, 2009. Pengembangan Media Pembelajaran bagi ABK, Bandung, h. 65

T. Sutojo, dkk, Kecerdasan Buatan, (Yogyakarta : C.V ANDI OFFSET, 2011)

Tamimuddin, Muh, Mengenal Mobile Learning, Artikel LIMAS, edisi 18, Juni 2017, h.1

Yekti, Resti dan Jaslin Ikhsan, Pengembangan Media Pembelajaran Berbasis Android pada Materi Kelarutan untuk Meningkatkan Performa Akademik Peserta Didik SMA, Jurnal Inovasi Pendidikan IPA, 2(1), 2016, h. 89.

Imronasofi, Pengertian serta kelebihan dan kekurangan AI, https://www.lyceum.id/artificialintelligence $/$, diakses pada tanggal 06 Maret 2018.

Sativa Riza, Metode Penelitian Research and Development, $\quad$ http://oryza sativa135rsh.blogspot.com $/ 2011 / 01 / \mathrm{me}$ tode-penelitian-research-and.html, diakses pada tanggal 08 Maret 2018. 
Maya, Software Aplikasi Mudah untuk. Membangun Aplikasi Android, https://prelo.co.id/blog/softwareaplikasi-mudah-untuk-membangunaplikasi-di-android, diakses pada tanggal 08 Maret 2018.
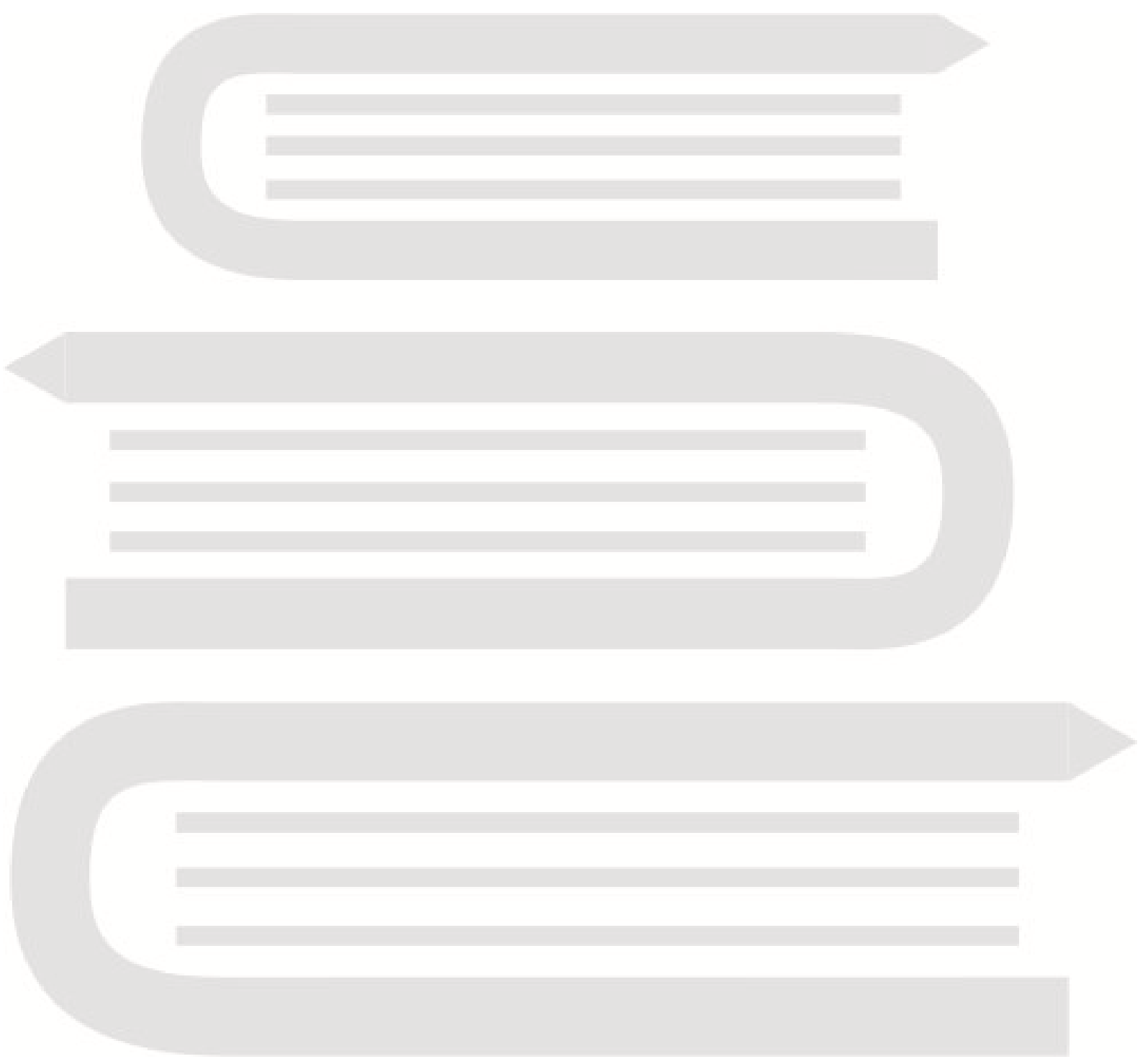